\title{
Estudo experimental da vertebroplastia: análise biomecânica e segurança da técnica
}

\author{
Experimental analysis of vertebroplasty: \\ biomechanic and techinical safety analysis
}

Alexandre Felipe França1 ${ }^{1}$ Tarcísı Eloy Pessoa de Barros Filho² , César Augusto Martins Pereira ${ }^{3}$

\section{RESUMO}

Analisou-se a segurança e a resistência mecânica de 30 corpos vertebrais, de cadáveres humanos, submetidos à vertebroplastia. Após a densitometria óssea, foram distribuídos em dois grupos A e B. Os do grupo A foram comprimidos até o segundo pico de força (Gráfico Força por Deformação), enquanto os do grupo B, até o primeiro. Injetou-se cimento acrílico no corpo vertebral por via transpedicular, observando-se seu extravasamento e a temperatura do corpo vertebral. Testou-se a resistência e comparou-se com a da própria vértebra quando íntegra. Esta técnica traz riscos às estruturas próximas, devido ao extravasamento do cimento.Quanto à temperatura, ela é segura desde que não ocorra o extravasamento. A resistência da vértebra, após o procedimento, depende do grau do achatamento inicial. Aquelas que tiveram achatamento menor apresentaram resistência maior.

Descritores: vertebroplastia, cimento ósseo.

\section{INTRODUÇÃO}

A osteoporose está associada às fraturas ósseas, produz dor, incapacidade e, indiretamente, pode até causar a morte. Diante disso, pode-se afirmar que produz um elevado custo social e financeiro para toda a sociedade. Salienta-se que os Estados Unidos gastaram, em 1995, 13 bilhões de dólares com os portadores de osteoporose, sendo que destes, seis bilhões foram gastos diretamente com o paciente; quatro bilhões em cuidados de enfermagem em casa e dois bilhões de dólares em outros serviços ${ }^{(32)}$.

Afirmaram $^{(16)}$ que a osteoporose causa uma nova fratura compressiva do corpo vertebral a cada 45 segundos, num total 700.000 novos casos por ano, e destes, 260.000 são sintomáticos, resultando um custo hospitalar de 800 milhões de dólares gastos com

\section{SUMMARY}

It was analyzed the safety and mechanical resistance of 30 vertebral bodies obtained from human cadavers submitted to "vertebroplasty" were analyzed. After bone "densitometry", they were distributed into two groups: $A$ and $B$. In group $A$, they were compressed to the second apex of force (graph by Force of Deformation), while in the group B, to the first. Acrylic cement was injected in the vertebral body by transpedicular access. It was observed the cement leakage and the temperature of the vertebral body. The resistance was tested and compared to the one of vertebrae not compressed before. The surrounding structures can be damaged due to the extravasation of the cement. Considering the temperature, this technique is safe, since extravasation does not take place. The resistance of the vertebra after the procedure is dependent on the degree of initial flattening, since bodies which had smaller flattening, presented the largest resistances.

Key words: vertebroplasty, bony cement.

\section{INTRODUCTION}

Osteoporosis is related to bone fractures, leading to pain, impairment and, indirectly even death. Thus, it can be stated that it produces a high social and financial cost to the society. The USA had in 1995 a total expense of 13 billion USD with osteoporosis, being 6 billion USD of direct expenditure with patients, 4 billion USD with nursery assistance and two with other services ${ }^{(32)}$.

This disease ${ }^{(16)}$ is said to cause a new compression fracture of a vertebral body every 45 seconds, with a total of 700.000 cases each year, 260,000 of them with no symptoms, resulting in a hospital cost of 800 million USD in 150.000 in hospital treatments. In average, patients with a compressi-

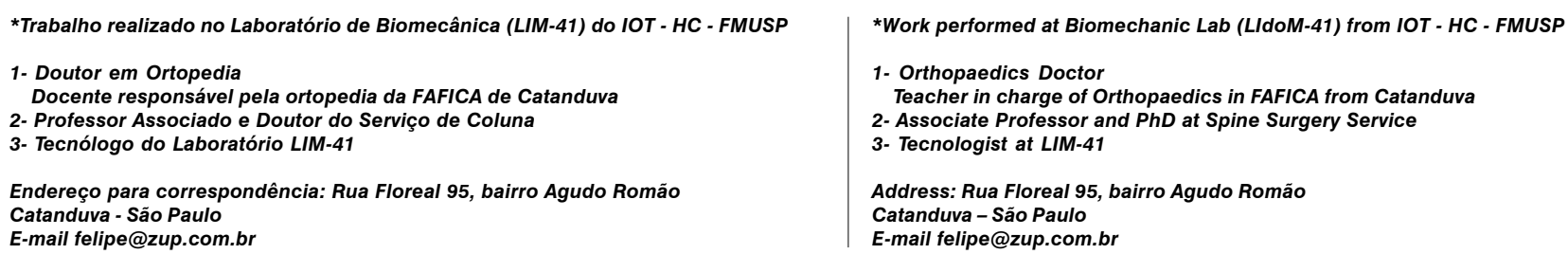


150.000 internações por ano. Em média, os pacientes com fraturas compressivas da coluna vertebral permanecem oito dias internados e 14 dias acamados pela dor.

A sintomatologia dolorosa do paciente portador de osteoporose e fratura da coluna vertebral é extremamente variada. Os autores relatam desde indivíduos assintomáticos até pacientes com dor intratável pelos métodos conservadores. Consideram que, em geral, a dor costuma ceder com medicamentos analgésicos, repouso, fisioterapia e, às vezes, algum tipo de órtese para imobilizar a coluna ${ }^{(31)}$. A cirurgia de estabilização da fratura da coluna vertebral associada à osteoporose é muito rara, porque, na maioria das vezes não existe compressão medular ou radicular capaz de produzir distúrbio neurológico. A indicação de cirurgia está restrita apenas àqueles pacientes com comprometimento neurológico ou portadores de dor intratável pelos métodos conservadores descritos acima( ${ }^{(19)}$

Os casos de indicação cirúrgica correspondem a $0,2 \%$ de todos os casos de osteoporose associada à fratura de coluna vertebral. No entanto, quando se faz necessário realizar a descompressão medular associada á fixação da coluna com osteoporose, estamos frente a um sério problema, pois, em geral, esses pacientes possuem outras desordens clínicas associadas que limitam a agressividade da cirurgia. Além disso, a qualidade do osso, nos pacientes portadores de osteoporose, não é a mais favorável para promover uma fixação rígida da fratura da coluna vertebral, e conseqüentemente, não se obtém uma estabilização adequada da mesma ${ }^{(19)}$.

Alguns autores, nos últimos anos, têm preconizado o emprego de uma técnica chamada de vertebroplastia, que consiste em injetar o cimento ósseo (polimetilmetacrilato), no interior do corpo vertebral, utilizando a via percutânea para a coluna cervical e a transpedicular para a dorsolombar. Esse tipo de abordagem permite recompor, rapidamente, a estabilidade mecânica da coluna vertebral e também o alívio rápido da dor do paciente ${ }^{(11,15,21,22)}$.

Em nosso trabalho objetivamos demonstrar se a técnica de vertebroplastia é um procedimento seguro para as estruturas anatômicas próximas ao corpo vertebral e também comparar a resistência biomecânica da vértebra fraturada após ser submetida a vertebroplastia com a resistência da vértebra íntegra.

\section{MATERIAL E MÉTODOS}

Foram retirados oito segmentos de colunas lombares, LI-LV, de cadáveres humanos, sete masculinos e um feminino, com idade variando dos 35 aos 72 anos e média de 51,87 anos. Quanto à raça, foram observados que cinco indivíduos eram da cor branca, dois pardos e um da cor negra, todos oriundos do Serviço de Verificação de Óbitos da Capital (São Paulo).

As peças foram obtidas de cadáveres frescos, posicionados em decúbito ventral, sendo o acesso à coluna feito por via posterior, na linha dos processos espinhosos, dissecando-se pele, subcutâneo e os músculos paravertebrais, expondo a coluna vertebral da décima vértebra torácica até o sacro. Removeu-se, cuidadosamente, em bloco, o segmento lombar; ressecaram-se todas as partes moles, permanecendo apenas as partes ósseas e os discos intervertebrais. As peças foram identificadas de acordo com o número do SVOC e acondicionadas em embalagens plásticas e congeladas a-20 graus Celsius. ve fracture of the spine remain in hospital for eight days, and 14 days in bed rest due to pain.

Painful symptoms of patients with osteoporotic spine fracture ranges very much. Authors report since totally asymptotic patients, up to pain not possible to manage by means of a conservative treatment. It is in general considered that the pain usually remits with analgesics, rest and physiotherapy, and eventually any kind of orthesis immobilizing the spine(31). A stabilizing surgery of a spine fracture due to osteoporosis is very rare, since in most of the cases there is no medullar or radicular compression that is able to produce a neurologic alteration. Surgery indication is restricted to the neurologically compromised patients, or those with pain that is untreatable through the above-mentioned methods ${ }^{(19)}$.

Cases with surgical indication are restricted to $0.2 \%$ of all osteoporosis cases related to spine fracture. However, when it is necessary to perform medullar decompression and fixation of osteoporotic spine, we face an important problem, since these patients generally have other associated clinical problems limiting the surgery extent. Additionally, the quality of the bone in osteoporotic patients is not favorable to allow a rigid fixation of a spine fracture, and consequently an adequate stabilization is hardly achieved(19).

Some authors have lately recommended the use of a technique called vertebroplasty, which consists in injecting bone cement (polymethylmetacrilate) inside the vertebral body, using a percutaneous way for cervical spine and transpedicular for dorso-lumbar. This kind of approach allows to rapidly restoring mechanical stability of the spine, as well as fast relief of patient's pain ${ }^{(11,15,21,22)}$.

In our work we aim to demonstrate if the vertebroplasty is a safe procedure for anatomical structures next to vertebral body, as well as to compare the biomechanical resistance of the fractured vertebra after submitted to vertebroplasty with the resistance of an healthy vertebra.

\section{MATERIALS AND METHODS}

Eight segments of lumbar spine, LI-LV were obtained from human cadavers, seven males and one female, ages Rangoon from 35 to 72 years, average 51.87 years. According to race, five were white, two non-whites, one black, all of them from the Serviço de Verificação de Óbitos da Capital (SVOC - São Paulo).

The parts were got from fresh bodies, positioned in ventral decubitus, accessing the spine through a posterior median approach, over spinous processes, dissecting skin, subcutaneous and paravertebral muscles from tenth thoracic vertebra to sacrum. Lumbar segment was carefully removed as a block, and soft tissues removed, remaining only bones and intervertebral discs. The pieces were numbered according to the SVOC number and packed in plastic bags, and then frozen at $-20^{\circ} \mathrm{C}$.

Identified and frozen spine segments were defrosted immersed in saline solution at $0.9 \%$ and took for bone densitometry in 
Os segmentos de coluna lombares identificados e congelados foram descongelados em soro fisiológico a 0,9\% e levados para realização do exame de densitometria óssea para se determinar a presença ou não de osteoporose, de acordo com os padrões da Organização Mundial deSaúde.

A densitometria foi realizada mergulhando-se o segmento de coluna lombar num recipiente plástico, contendo cinco litros de água. O segmento lombar foi imobilizado com paralelepípedos plásticos de densidade maior que a da água. O aparelho que realizou o exame foi da marca Lunar ${ }^{\circledR}$ modelo DPX, e, para emitir seu laudo, necessita-se do peso, altura, idade e sexo do doador da coluna vertebral.

As duas colunas excluídas pela densitometria óssea, por terem densidade óssea com desvio padrão 2,50 abaixo da população referência, que é até quarenta anos, foram utilizadas em ensaios preliminares, mas não foram incluídas para fins estatísticos.

Os ensaios preliminares foram realizados para se estudar o comportamento biomecânico da vértebra lombar submetida a cargas compressivas. Estes ensaios foram registrados em gráficos de força versus deformação. Observou-se que o gráfico, quando a vértebra é comprimida, apresenta uma curva ascendente até atingir um primeiro pico de força, em seguida, ocorre uma curva descendente, denominada de vale e, por fim, uma retomada do aumento da força aplicada até atingir um segundo pico de força. Após este último pico de força, acontece o patamar de carga, relacionado com a compactação máxima da vértebra (Figura 1).

Os seis segmentos de colunas lombares remanescentes foram divididos em dois grupos: A e B. Cada um contendo três segmentos de coluna lombar. As vértebras do grupo A foram submetidas aos seguintes procedimentos: preparação do corpo de prova, ensaio de compressão da vértebra íntegra, vertebroplastia, observação dos parâmetros de segurança e ensaio de compressão pós vertebroplastia.

No grupo B, as vértebras foram submetidas aos mesmos procedimentos do grupo A, entretanto, a compressão da vértebra íntegra foi menor. Os corpos vertebrais íntegros do grupo A foram comprimidos até o início do patamar de força no gráfico "força por deformação" e nas vértebras íntegras do grupo B, a força de compressão cessou no primeiro pico de força.

Cada segmento de coluna lombar era composto por cinco vértebras denominadas LI, LII, LIII, LIV e LV, que foram separados ao nível do disco intervertebral, resultando em unidades. Cada unidade vertebral foi identificada pela letra do seu grupo A ou $\mathrm{B}$ e por um número arábico de um a três que corresponde ao número do segmento lombar, acrescido de sua denominação anatômica, por exemplo, A2LI e B3LIV. order to detect whether or not osteoporosis was present, according to World Health Organization standards.

Bone densitometry was performed by immersion of the spine segment in a plastic recipient with five liters of water. The segment was immobilized using plastic bricks with higher density in relation to water. The equipment used was a Lunar ${ }^{\circledR}$ model DPX, and the analysis result took into consideration weight, height, age and gender of the donator.

The two samples withdrawn due to densitometry results with more than 2.5 standard error bellow reference population, i.e. up to forty years, were used in preliminary assays however not included in statistical analysis.

Preliminary assays were performed to study the biomechanical behavior of lumbar vertebrae submitted to compressive loads. These assays were recorded in graphs of force versus deformation. It was observed that when a vertebra is compressed the graph presents an ascending curve up to reach a first force peak, and following a descending curve, called trough and finally a retake of the applied force up to a second force peak. After this last force peak, there is a load plateau related to the maximal compactation of the vertebra (Figure 1).

The six spine segments left were divided into two groups: $A$ and $B$, with three spine segments each. Vertebrae from group A were submitted to the following: preparation of proof body, intact vertebra compression assay, vertebroplasty, observation of safety parameters and post vertebroplasty compression assay.

In group $B$, vertebrae were submitted to the same procedures of those from group $A$, however the compression over the intact vertebra was smaller. Intact vertebral bodies from group A were compressed up to the start of the force plateau in the graph and in group A compression ceased at the first force peak.

Each spine segment was composed by five vertebrae called LI, LII, LIII, LIV and LV, which were separated at intervertebral disc level resulting in units. Each vertebral unit was identified by a letter from its group, A or B, and for an arabian number one to three corresponding to the number of the lumbar segment, plus its anatomical designation, for instance, A2LI and B3LIV.

\section{PREPARATION OF THE PROOF BODY}

The proof body for the assay was prepared initially measuring the height of the vertebral body at its central portion, using a 


\section{PREPARAÇÃO DO CORPO DE PROVA}

Preparou-se o corpo de prova para o ensaio, medindo-se, inicialmente, a altura do corpo vertebral na sua porção central, através de um paquímetro digital com resolução de um centésimo de milímetro da marca Mitutoy ${ }^{\circledR}$. No passo seguinte, cimentou-se o corpo vertebral a dois cilindros metálicos: um superior e outro inferior. Para isto, misturaram-se $150 \mathrm{~g}$ de pó de copolímero acrílico auto polimerizante e $50 \mathrm{ml}$ de monômero líquido de metilmetacrilato da marca Jet ${ }^{\circledR}$ para uso odontológico. A cimentação do corpo vertebral, além de fixá-lo aos cilindros metálicos, permite preencher as irregularidades das superfícies, superior e inferior do corpo vertebral, proporcionando uma melhor distribuição dastensões. Oalinhamento e o ajuste da altura dos cilindros metálicos em relação à altura do corpo vertebral durante o período de secagem do polimetilmetacrilato, foram garantidos por meio de um dispositivo, denominado dispositivo de cimentação (Figura 2). Esse dispositivo possui dois aros metálicos, cujo diâmetro interno permitia o encaixe dos cilindros metálicos do corpo de prova. Os cilindros metálicos do corpo de prova, encaixados dentro dos aros, eram fixados entre si através de parafusos, que prendiam o conjunto em três pontos, fixando, assim, os cilindros aos aros. A altura uniforme entre os conjuntos cilindros metálicos/aros foi mantida por três barras rosqueadas, colocadas de forma perpendicular aos conjuntos. As barras atravessavam os aros metálicos por orifícios e eram presas a estes por porcas.

\section{ENSAIO DE COMPRESSÃO}

Os ensaios biomecânicos foram realizados na Máquina Universal de Ensaios Mecânicos Kratos 5002 dotada de célula de carga de cinco tfe conectada a um computador pessoal dotado de um software desenvolvido pelo Laboratório de Biomecânica LIM-41 do Instituto de Ortopedia e Traumatologia do Hospital das Clínicas da Faculdade de Medicina da Universidade de São Paulo, com a função de armazenar as informações provenientes da máquina de ensaios, como o deslocamento e a força medida pela célula de carga (Figura 3).
Mitutoy ${ }^{\circledR}$ digital pachimeter with a centi-mm precision. Next step was to cement the vertebral body to two metal cylinders, above and below. For this it was used $150 \mathrm{mg}$ of powder of acrylic polymer with $50 \mathrm{ml}$ of methylmetacrylate liquid monomer brand Jet ${ }^{\circledR}$ for odontologic use. Cementing the vertebral bodies, besides fixing it to the metal cylinders allows fulfilling eventual irregularities of the superior and inferior surfaces of the vertebral bodies, allowing a better distribution of the tensions. The alignment and adjust of height of vertebral bodies during hardening of methylmetacrylate were granted by a device called cementation device (Figure 2). This device has two metallic rings, with an internal diameter allowing fitting the metallic cylinders. The metallic cylinders of the proof body were connected to each other by screws, fixing them by three points, thus fixating the cylinders to the rings. The uniform height between the sets metallic cylinders/rings was kept by three threaded rods placed perpendicularly to the sets. The rods crossed the rings through holes and fixed to them by nuts.

\section{COMPRESSION ASSAY}

Biomechanical assays were performed in a Kratos 5002 Universal Mechanical Assay Machhine, with a load cell of five tf and connected to a PC with a software developed by the LIM-41 Biomechanics Laboratory from Instituto de Ortopedia e Traumatologia do Hospital das Clínicas da Faculdade de Medicina da Universidade de São Paulo, for saving data from the assay machine, such as force displacement and measured force by load cell (Figure 3).

Compression assays were performed by using a mechanical device allowing to apply the load application and correct positioning of proof body together in relation to the assay machine. 
Os ensaios de compressão foram realizados, utilizando-se um dispositivo mecânico que permitia a aplicação da carga e o correto posicionamento do corpo de prova junto à máquina de ensaios.

Com o movimento descendente do travessão móvel da máquina de ensaios, a célula de carga (Figura 4-A) aplica uma carga compressiva sobre o corpo de prova através de uma haste rosqueada (Figura 4-B), acoplada ao atuador (Figura 4-C), através de uma articulação do tipo taça-esfera. O corpo de prova (Figura 4-F) era englobado por um cilindro superior (Figura 4-D) e outro inferior (Figura 4-E) estando este último acoplado a um cilindro (Figura 4-G) e a um tubo (Figura 4-H) que serviam como base de apoio (Figura 4-I).

Os ensaios de compressão das vértebras íntegras para os grupos $A$ e $\mathrm{B}$, diferenciaram-se no que diz respeito à deformação sofrida, pois, no grupo A, a compressão era realizada até uma deformação referente ao início do patamar de força e no grupo B, a deformação ocorria até o primeiro pico de força (Figura 1).

Após a vertebroplastia, as vértebras de cada grupo foram submetidas, novamente, ao ensaio de compressão. O critério para interrupção do ensaio foi relacionado a força registrada, ou seja, quando essa carga fosse igual ou superior à força máxima encontrada no ensaio prévio da vértebra íntegra.

Os ensaios de compressão da vértebra íntegra e submetida à vertebroplastia para os grupos A e B foram relacionados, com o objetivo de comparar a rigidez e as deformações sofridas.

Arigidezé definida como a razão da variação da força e a variação da deformação entre dois pontos pertencentes à região linear da curva (Figura 5) e é expresso em N/mm.

Para a determinação das deformações sofridas, durante o ensaio de compressão, utilizou-se como referência a força de pico no ensaio íntegro (FPico) e a sua deformação (DPint). Com a projeção de FPico, na curva do ensaio de vertebroplastia, foi possível encontrar a sua deformação (DPVer) referente à mesma força aplicada (Figuras 6, 7, 8, 9).

\section{VERTEBROPLASTIA}

O pedículo vertebral foi perfurado com uma broca de $3,5 \mathrm{~mm}$ de diâmetro e, em seguida, canulado por um tubo plástico com cinco cm de extensão, até atingir o interior do corpo vertebral, garantindo desta maneira, que o cimento acrílico fosse injetado para dentro do corpo vertebral. A perfuração do pedículo vertebral ocorreu no ponto de intersecção de duas linhas imaginárias traçadas; a primeira, passando em direção hori-
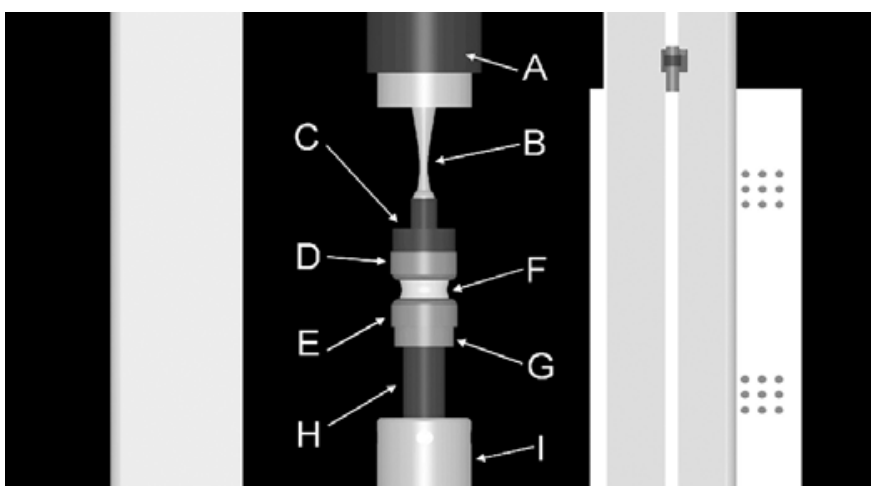

Figura 4 - Desenho ilustrativo do dispositivo mecânico para ensaio de compressão onde: $\boldsymbol{A}$ - Célula de carga, B - Haste do atuador, C - Atuador, D - Cilindro superior, E - Cilindro inferior, $\boldsymbol{F}$ - Corpo de prova, $\mathbf{G}$ - Cilindro de apoio, $\boldsymbol{H}$ - Tubo de apoio, I - Base da máquina,

Figure 4 - Illustrative drawing of the mechanical device for compression assay where: A - Load cell, B - Mobile bar,

C - Actuator, D - Superior cylinder, E - Inferior cylinder,

$\boldsymbol{F}$ - Proof body, G - Supporting cylinder,

$\boldsymbol{H}$ - Supporting tube, I - Machine's basis

As the mobile bar of the assay machine moves down the load cell (Figure 4-A) applies a compressive load over the proof body threaded rod (Figure 4-B), connected to the actuator (Figure 4-C) through a ball and socket joint. The proof body (Figure 4-F) was involved by a superior cylinder (Figure 4-D) as well as byan inferior (Figure 4-E) and the latest was connected to a cylinder (Figure 4-G) and to a tube (Figure 4-H) which served as support.

Compression assay of intact vertebrae for groups A and B differentiated in regard to the deformation they were submitted, since in group $A$ compression was performed up to a deformation related to the start of the force plateau, and in group $B$ compression was performed up to the first force peak (Figure 1).

After the vertebroplasty, vertebrae of each group were again submitted to compression assay. Criterion for stopping the assay was related to the recorded force, that is, when this load was equal or superior to the maximal force found in the previous intact vertebrae assay.

Compression assay of intact vertebra and submitted to vertebroplasty for groups A and B were related to the objective of comparing 
zontal pelo meio do processo transverso vertebral; a segunda, em direção vertical, que passa pelo centro da faceta articular vertebral.

Foram misturados 40 gramas de um pó (composto por 30 gramas de copolímero de metilmetacrilato, seis gramas de polimetilmetacrilato e quatro gramas de sulfato bárico) com 20 ml de monômero líquido $(19,5 \mathrm{ml}$ metacrilato de metila, $0,5 \mathrm{ml} \mathrm{N}, \mathrm{N}$ dimetil paratoluidina e 1,5 mg dehidroquinona). Estecimento acrílico utilizado é o Simplex $^{\circledR}$, da Howmedica ${ }^{\circledR}$. Após a mistura, foi obtidauma massadeconsistência deglacê de bolo, que foi injetadano interior do corpo vertebral através do pedículo vertebral canulado com o tubo plástico. O volume de cimento acrílico injetado foi de $9 \mathrm{ml}$, e, para injetá-lo, foi utilizada uma seringa de plástico de $20 \mathrm{ml}$, acoplada à extremidade externa do tubo plástico que foi introduzido dentro do corpo vertebral. Foram observados, logo após a vertebroplastia, os parâmetros de segurança para os dois grupos A e B, que consistiram em anotar por onde extravasou o polimetilmetacrilato eamedidada temperatura junto à parede posterior do canal vertebral.

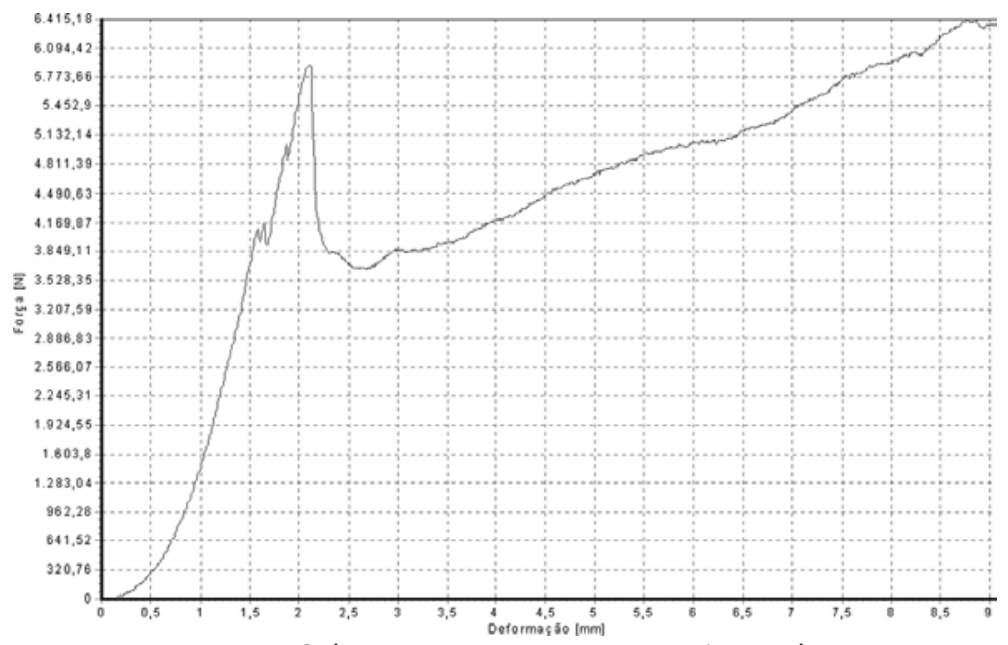

Figura 6 - Gráfico do ensaio de compressão da vértebra $L I$ do segmento $n^{\circ} 1$ do grupo $A$.

Figure 6- Graph of intact LIV segment 1 group A vertebra compression assay.

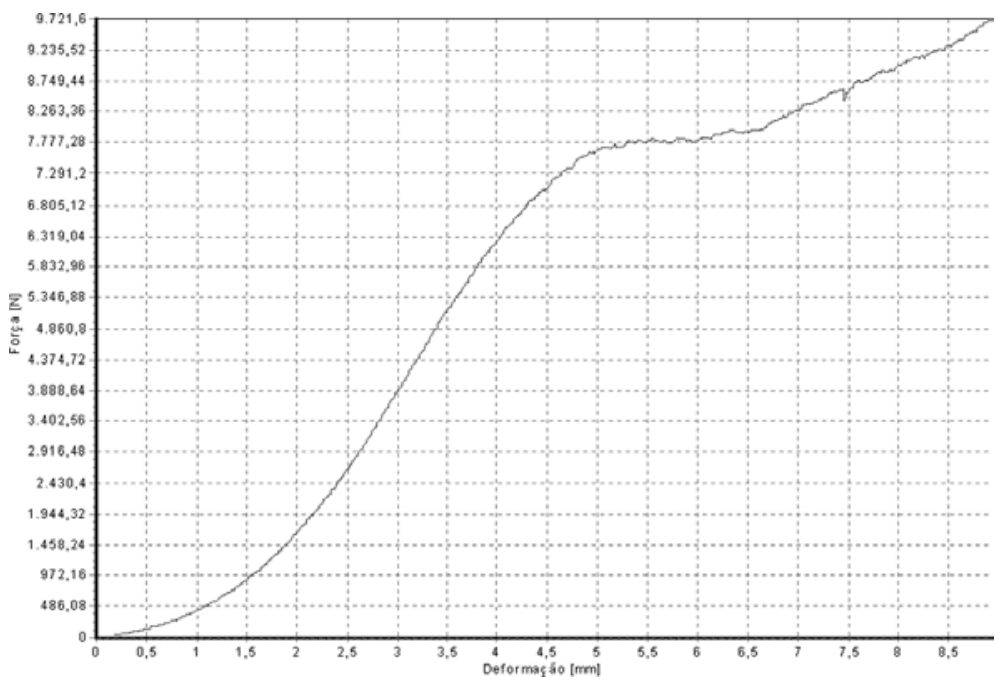

Figura 7 - Gráfico do ensaio de compressão da vértebra $L I$ do segmento $n^{\circ} 1$ do grupo A, após vertebroplastia.

Figure 7 - Graph of intact LIV segment 1 group A after vertebra compression assay. the rigidity and the deformations.

Rigidity is defined as the relation between force variation and deformation variation between two points belonging to the linear region of the curve (Figure 5) and expressed in $\mathrm{N} / \mathrm{mm}$.

For determining the deformations, during the compression assay it was used as reference the peak force in intact assay (FPico) and its deformation (DPint). By projecting FPico over vertebroplasty assay curve, it was possible to find the deformation (DPVer) related to the same applied force (Figures $6,7,8,9)$.

\section{VERTEBROPLASTY}

The vertebral pedicle was perforated with a 3.5 $\mathrm{mm}$ drill, and cannulated by a plastic tube $5 \mathrm{~cm}$ long up to reach inside vertebral body, thus granting the acrylic cement to be injected inside the vertebral body. Perforation of the pedicle was made at the intersection point between two imaginary lines, the first horizontal through the middle of the transversal processes of the vertebra and the second, vertical, crossing

\section{PARÂMETROS DE SEGURANÇA}

Os parâmetros de segurança foram divididos quanto à temperatura e o extravasamento do cimento ósseo para dentro do canal durante o procedimento de vertebroplastia.

Amedida da temperatura foi realizada, logo após a injeção do cimento acrílico por via transpedicular, colocando dois sensores de temperatura (termo-resistores, modelo PT-100) em contato com a parede posterior do canal do corpo vertebral (Figura 10): um do lado direito; outro, do esquerdo. O registro da temperatura foi realizado por um pirômetro RoberShaw ${ }^{\circledR}$, modelo LDT 900 . Como medida foi considerada aquela obtida antes da injeção do cimento acrílico, denominada TO. As demais medidas foram efetuadas, logo após a vertebroplastia, com um intervalo entre elas de um minuto, por um período de 15 minutos. the middle of the articular facet.

A mixture of $40 \mathrm{~g}$ of a powder (composed by $30 \mathrm{~g}$ of copolymer of methylmetacrylate, $6 \mathrm{~g}$ of polymethylmetacrylate and $4 \mathrm{~g}$ of barium sulfate) with $20 \mathrm{ml}$ of liquid monomer $(19.5 \mathrm{ml}$ of methyl metacrylate, $0.5 \mathrm{ml}$ N, N-dimethyl paratoluidine and $1.5 \mathrm{mg}$ of hydroquinone). The use acrylic cement is the Simplex ${ }^{\circledR}$ from Howmedi$\mathrm{ca}^{\circledR}$. After the mixture a soft paste was obtained which was injected inside the vertebral body through the vertebral pedicle cannulated with the plastic tube. The injected volume of acrylic cement was of 9 $\mathrm{ml}$ and for injecting it was used a plastic syringe of $20 \mathrm{ml}$ connected to the plastic tube. Just after the vertebroplasty the safety parameters were checked for both groups, $A$ and $B$, consisting in observing the places from where the cement leaked and measuring the temperature next to posterior wall of vertebral canal. 
Os sensores de temperatura foram envoltos por uma pasta, quando colocados no canal vertebral. Essa pastamelhoraa condutibilidade térmica entre a parede do canal e os sensores.

O outro parâmetro, para analisarmos a segurança da vertebroplastia foi verificar por onde extravasou cimento acrílico, após a injeção do mesmo por via transpedicular. Observamos, dessa maneira, se o polimetilmetacrilato extravasou para fora do canal vertebral, para dentro do canal ou se não houve extravasamento.

\section{ANÁLISE ESTATÍS- TICA}

Realizou-se a distribuição de freqüência absoluta e relativa dos parâmetros qualitativos e estatística descritiva dos parâmetros quantitativos classificados como média (M), desvio padrão (DP), erro padrão da média (EPM), valor máximo (Max), valor mínimo (Min), intervalo (Inter) e número total de amostras (N).

Utilizou-se o teste exato de Fisher, para as comparações entre os parâmetros qualitativos e os testes de Wilcoxon, $U$ de Mann Whitney et de Student, para as comparações dos parâmetros quantitativos.

Os parâmetros quantitativos analisados foram às temperaturas medidas na região postero-lateral direita e esquerda dos corpos vertebrais lombares, quanto aos ensaios de compressão dos corpos vertebrais lombares divididos nos grupos A e B, analisou-se também, a rigidez, variação percentual entre a altura inicial da vértebra e sua deformação até o $1^{\circ}$ pico, variação percentual entre a altura inicial da vértebra e sua deformação final e a variação percentual entre a rigidez do grupo $A$ e $B$.

\section{SAFETY PARAMETERS}

The safety parameters were divided regarding temperature and cement leakage to the canal during the process of vertebroplasty.

Temperature measurement was performed justafter transpedicular injection of acrylic cement by the placement of two temperature sensors (thermo-resistors model PT-100) in contact with the posterior wall of the vertebral body (Figure 10), one at the right side, the other one at the left side. Recording of the temperature was started by a RoberShaw ${ }^{\circledR}$ pyrometermodel $D T$ 900. As measure it was considered the obtained just before injecting the cement, called TO. The remaining measurements were performed just after the vertebroplasty with one-minute interval between them, for a period of 15 minutes.

Temperature sensors were involved by a paste, when placed in vertebral canal. This paste improves thermic conductibility between the wall and the sensors.

The other parameter used in observing safety of vertebroplasty was checking the places where the cement leaked from after its injection. We observed thus if the cement leaked outside of vertebral canal, into the canal or if there was no leakage.

\section{ANALYSIS STATISTICS}

Frequency distribution both absolute and relative of the qualitative parameters, and descriptive of the quantitative dada was performed, and classified as mean (M), standard deviation (DP), standard deviation of the mean (EPM), maximum value (Max), minimum value (Min), interval (Inter) and total number of samples (N).

Exact Fischer's test was use for comparing qualitative parameters, and Wilcoxon, Mann Withney's U, and t Student test were used for quantitative parameter comparison.

The quantitative parameters analyzed were the measured temperatures at posterior lateral right and left parts of vertebral bodies; 
Em todas as comparações, adotou-se o nível de significância de 5 $\%(=0, .05)$ e os resultados significantes foram identificados por asteriscos.

\section{RESULTADOS}

Os resultados referentes aos parâmetros de segurança, o local de extravasamento e a temperatura da cortical posterior do corpo após a vertebroplastia, estão listados nas (Tabelas de 1 a 3). Ressaltando que os $N=16$, das (Tabelas 2 e 3) refere-se ao número de me-

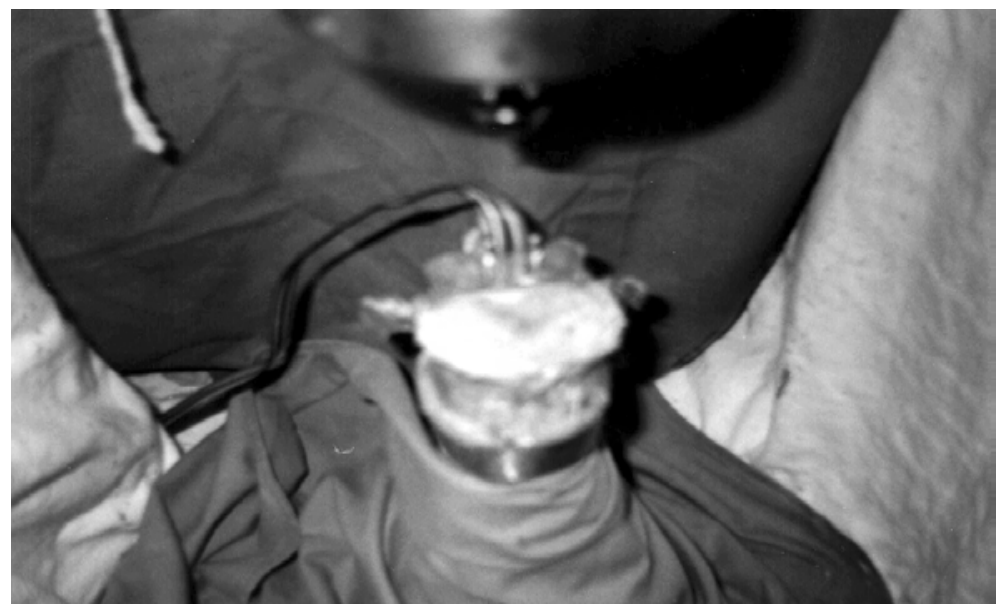

Figura 10 - Sensores introduzidos no canal do corpo vertebral para obtenção das temperaturas, após a injeção de cimento ósseo por via transpedicular.

Figure 10 - Temperature sensors placed inside vertebral canal, to evaluate temperature after transpedicular cement injection. regarding the compression assays of lumbar vertebral bodies (groups $A$ and $B$ ) it was also analyzed the rigidity, the percentual range of initial vertebral height and its deformation up to the $1^{\text {st }}$ peak, percentual range between initial vertebra height and its final deformation and the percentual range between rigidity of groups $A$ and $B$.

In all comparisons, a significance level of $5 \%$ $(=0.05)$ was used, and significant results noted with asterisk.

\section{RESULTS}

Results regarding safety parameters, local of leakage and posterior cortical temperature after vertebroplasty, are listed in (Tables 1 to 5), stressing that $N=16$ in (Tables 3 and 4) refer to the number of measurements of temperature performed in each tested vertebral body.

Biomechanical results are listed in (Tables 6 to 12). Tables 6 to 9 compare biomechanical findings within each group, while (Tables 10 to 12) compare results between groups $A$ and $B$.

\begin{tabular}{|c|c|c|c|c|c|c|c|c|c|c|}
\hline & \multicolumn{10}{|c|}{ Temperatura ${ }^{\circ} \mathrm{C}$} \\
\hline & \multicolumn{2}{|c|}{ LI } & \multicolumn{2}{|c|}{ LII } & \multicolumn{2}{|c|}{ LIII } & \multicolumn{2}{|c|}{ LIV } & \multicolumn{2}{|c|}{ LV } \\
\hline & E & D & E & D & $\mathrm{E}$ & D & E & $\mathrm{D}$ & E & $\mathrm{D}$ \\
\hline M & 24,68 & 25,72 & 26,17 & 28,55 & 26,21 & 28,87 & 26,69 & 28,09 & 27,74 & 29,88 \\
\hline DP & 0,83 & 0,59 & 0,91 & 1,29 & 0,26 & 0,79 & 0,60 & 1,50 & 1,04 & 1,24 \\
\hline EPM & 0,21 & 0,15 & 0,23 & 0,32 & 0,06 & 0,20 & 0,15 & 0,37 & 0,26 & 0,31 \\
\hline Min & 23,8 & 25,0 & 25,1 & 26,6 & 25,92 & 27,67 & 25,7 & 26,3 & 26,40 & 27,58 \\
\hline Max & 26,2 & 26,7 & 28,2 & 30,2 & 26,87 & 29,77 & 27,8 & 31,1 & 29,67 & 32,35 \\
\hline Inter & 2,4 & 1,7 & 3,1 & 3,6 & 0,95 & 2,1 & 2,1 & 4,8 & 3,27 & 4,77 \\
\hline $\mathrm{N}$ & 16,00 & 16,00 & 16,00 & 16,00 & 16,00 & 16,00 & 16,00 & 16,00 & 16,00 & 16,00 \\
\hline & $\cdots$ & & $|\cdots+\cdots|$ & & & $\ldots$ & & $\cdots+$ & & \\
\hline & $t=-4$ & & $t=-6,05$ & & 12,8 & $t=-3$ & & $=-5,26$ & & \\
\hline & $\mathrm{p}=0,00$ & & $=1,84 \mathrm{E}-6^{*}$ & $p=1$ & 7E-10* & $\mathrm{p}=0,0$ & & 0,00001 & & \\
\hline
\end{tabular}

Tabela 2 - Média das temperaturas medidas na região posterolateral direita $(D)$ e esquerda $(E)$ dos corpos vertebrais lombares I a $V$, antes e após a injeção de PMMA pelo pedículo direito em um período de 0 a 15 minutos, com intervalos de um minuto, comparações pelo teste de $t$ de Student.

Table 2 - Average of temperatures measured in posterior lateral region right $(D)$ and left $(E)$ of vertebral bodies lumbar I to $V$ before and after injection of PMMA through the right pedicle in a period of 0 to 15 minutes, with one minute interval. Comparisons by $t$ Student test.
Tabela 1 - Distribuição de freqüência absoluta e relativa dos grupos $A$ e $B$, segundo o local de extravasamento.

Table 1 - Distribution of absolute and relative frequency of groups $A$ and $B$ according to place of leakage.

SE: sem extravasamento CEI: com extravasamento intra-carnal CEE: com extravasamento extra-carnal CEA: com extravasamento intra e extra-carnal 


\begin{tabular}{c|c|c}
\hline & Temperatura max. $\left[{ }^{\circ} \mathrm{C}\right]$ & $\begin{array}{c}\text { Tempo } \\
{[\mathrm{min}]}\end{array}$ \\
\hline $\mathrm{M}$ & 31,92 & 7,97 \\
\hline $\mathrm{DP}$ & 6,30 & 5,35 \\
\hline $\mathrm{EPM}$ & 1,15 & 0,98 \\
\hline Min & 24,10 & 0,00 \\
\hline Max & 53,30 & 15,00 \\
\hline
\end{tabular}

Tabela 3 - Temperatura máxima medida na região postero-lateral direita dos 30 corpos vertebrais lombares de I a $V$ e seu respectivo tempo até atingir a temperatura máxima.

Table 3 - Maximum temperature measured at posterior lateral right region of the 30 vertebral bodies I to $V$ and respective time to reach maximum temperature.

\begin{tabular}{c|c|c}
\hline \multirow{2}{*}{} & \multicolumn{2}{|c}{ Rigidez [N/mm] } \\
\cline { 2 - 3 } & Integro & Vertebroplastia \\
\hline DP & 5517,35 & 3647,50 \\
\hline EPM & 2850,85 & 2005,14 \\
\hline Min & 736,09 & 517,72 \\
\hline Max & 10898,75 & 533,26 \\
\hline N & 15,00 & 8000,02 \\
\hline Wilcoxon & W $=110$ & 15,00 \\
\hline
\end{tabular}

Tabela 4 - Rigidez medida pelos ensaios de compressão dos corpos vertebrais lombares de I a V íntegros e, posteriormente, submetidos à vertebroplastia referentes ao grupo A, comparação pelo teste de Wilcoxon.

Table 4 - Rigidity as measured by compression assay of the lumbar vertebral bodies I to $V$ intact and, afterwards, submitted to vertebroplasty. Group A. Comparison by Wilcoxon test.

\begin{tabular}{c|c|c}
\hline \multirow{2}{*}{} & \multicolumn{2}{|c}{ Rigidez [N/mm] } \\
\cline { 2 - 3 } M & Integro & Vertebroplastia \\
\hline DP & 3720,84 & 3424,64 \\
\hline EPM & 1122,07 & 1348,70 \\
\hline Min & 289,72 & 348,23 \\
\hline Max & 1927,80 & 709,74 \\
\hline N & 6127,46 & 5689,44 \\
\hline Wilcoxon & 15,00 & 15,00 \\
\hline
\end{tabular}

Tabela 5 - Rigidez medida pelos ensaios de compressão dos corpos vertebrais lombares de I a $V$ íntegros e, posteriormente, submetidos à vertebroplastia referentes ao grupo $B$, comparação pelo teste de Wilcoxon.

Table 5 - Rigidity as measured by compression assays of vertebral bodies lumbar I to V, intact and, afterwards, submitted to vertebroplasty. Group B. Comparison by Wilcoxon test.

\begin{tabular}{c|c|c}
\hline \multirow{2}{*}{} & \multicolumn{2}{|c}{$\square$ Pico [\%] } \\
\cline { 2 - 3 } M & Integro & Vertebroplastia \\
\hline DP & 11,88 & 22,45 \\
\hline EPM & 10,65 & 12,61 \\
\hline Min & 3,75 & 3,26 \\
\hline Max & 42,01 & 7,39 \\
\hline N & 15,00 & 51,96 \\
\hline Wilcoxon & W $=-102$ & 15,00 \\
\hline
\end{tabular}

Tabela 6 - Variação percentual entre a altura inicial da vértebra e sua deformação até o $1^{\circ}$ pico ( Pico), durante o ensaio de compressão dos corpos vertebrais lombares íntegros de I a V e submetidos à vertebroplastia referentes ao grupo $A$, comparação pelo teste de Wilcoxon.

Table 6 - Percentual range between initial vertebra height and its deformation up to the first peak ( Pico), during compression assay of intact vertebral bodies I to $V$ and submitted to vertebroplasty - group A, comparison by Wilcoxon test.

\begin{tabular}{c|c|c}
\hline \multirow{2}{*}{} & \multicolumn{2}{|c}{$\square$ Pico [\%] } \\
\cline { 2 - 3 } M & Integro & Vertebroplastia \\
\hline DP & 8,89 & 14,18 \\
\hline EPM & 2,61 & 7,70 \\
\hline Min & 0,67 & 1,99 \\
\hline Max & 13,61 & 7,78 \\
\hline N & 15,00 & 34,25 \\
\hline Wilcoxon & W $=-118$ & 15,00 \\
\hline
\end{tabular}

Tabela 7 - Variação percentual entre a altura inicial da vértebra e sua deformação até o $1^{\circ}$ pico ( Pico), durante o ensaio de compressão dos corpos vertebrais lombares íntegros de I a V e submetidos à vertebroplastia referentes ao grupo $B$, comparação pelo teste de Wilcoxon.

Table 7 - Percentual range between initial height of the vertebra and its deformation up to the first peak ( Pico), during the compression assay of intact vertebral bodies I to $V$ and submitted to vertebroplasty, group $B$, comparison by Wilcoxon test. 


\begin{tabular}{c|c|c}
\hline \multirow{2}{*}{} & \multicolumn{2}{|c}{$\square$ Total [\%] } \\
\cline { 2 - 3 } M & Grupo A & Grupo B \\
\hline DP & 23,34 & 9,37 \\
\hline EPM & 11,84 & 2,62 \\
\hline Min & 3,06 & 0,68 \\
\hline Max & 5,15 & 5,51 \\
\hline N & 48,22 & 13,99 \\
\hline U de Mann Whitney & 15,00 & 15,00 \\
\hline
\end{tabular}

Tabela 8 - Variação percentual entre a altura inicial da vértebra e sua deformação final ( Total) durante o ensaio de compressão dos corpos vertebrais lombares íntegros de I a V segundo o grupo $A$ e $B$, comparação pelo teste de $U$ de Mann Whitney.

Table 8 - Percentual range of initial height of the vertebra and its final deformation ( Total) during the compression assay of the vertebral bodies of intact lumbar I to $V$ according to the group $A$ or $B$, comparison by $\cup$ Mann's test.

dessa enfermidade na população mundial, principalmente, naqueles países que experimentaram uma melhoria nas suas condições de alimentação e saúde. Como conseqüência, apresentaram um aumento na expectativa de vida da sua população, fato notado e relatado por alguns autores ${ }^{(25.32)}$

Definiram(17) osteoporose como a condição do esqueleto, caracterizada pela diminuição da densidade mineral óssea (massa/volume) de um osso, que estava normalmente mineralizado, o suficiente para produzir fraturas ao mínimo trauma.

O densitômetro é o aparelho de escolha para medir a densidade mineral óssea, pois ele possui uma margem de erro de 5 a $10 \%$ para a sensibilidade e $2 \%$ para especificidade ${ }^{(13)}$.

A Organização Mundial de Saúde classificou a densidade óssea obtida pela densitometria em três categorias: normal como o paciente que tiver massa óssea de até um desvio padrão da média da população jovem, até quarenta anos, utilizada como referência. Outra categoria é o paciente com osteopenia, que compreende aquele indivíduo com resultado densitométrico de 1 a 2,5 desvios padrões abaixo da população referência. A última categoria foi definida como portador de osteoporose aquele que possuir resultado da densidade óssea abaixo de 2,5 desvios padrões da média da população referência.

A fratura de coluna vertebral associada à osteoporose ocorre em $16 \%$ das mulheres brancas americanas, após a menopau$\mathrm{sa}^{(25)}$. Essas pacientes deverão ser tratadas, na sua grande maioria, de forma conservadora, com medicamentos para a dor, antiinflamatórios, órteses, repouso e fisioterapia.

O tratamento cirúrgico da fratura de coluna associado à osteoporose é muito raro, estando indicado apenas àqueles pacientes com dor intratável pelos métodos conservadores e com compressão neurológica associada ${ }^{(19,31)}$.

\begin{tabular}{c|c|c}
\hline \multirow{2}{*}{} & \multicolumn{2}{|c}{$\square$ Rig [\%] } \\
\cline { 2 - 3 } M & Grupo A & Grupo B \\
\hline DP & 32,52 & 7,09 \\
\hline EPM & 26,00 & 32,26 \\
\hline Min & 6,71 & 8,33 \\
\hline Max & $-13,71$ & $-51,32$ \\
\hline N & 78,05 & 68,47 \\
\hline U de Mann Whitney & U $=61$ & 15,00 \\
\hline
\end{tabular}

Tabela 9 - Variação percentual ( Rig) entre a rigidez dos corpos vertebrais lombares íntegros de $I$ a $V$ e submetidos a vertebroplastia segundo o grupo $A$ e $B$, comparação pelo teste de $U$ de Mann Whitney.

Table 9 - Range variation ( Rig) between rigidity of intact lumbar vertebral bodies I to $\mathrm{V}$ and submitted to vertebroplasty - group A or B - comparison by U Mann Whitney test.

\section{DISCUSSION}

The spine can be affected by a number of diseases resulting in bone mass reduction, thus increasing the fragility of the vertebral body. Among these, we highlight hemangiomas, lythic tumors and osteoporosis. We understand that bone mass reduction leads to a bone that is unable to resist mechanical and physiological requirements, resulting in vertebral body fractures and their consequences, such as nerve compressions, kyphosis, scoliosis and frequently an important picture of pain ${ }^{(1)}$.

Among the above mentioned diseases, osteoporosis is deserving special attention from several specialties, due to an increasing number of these conditions among world population, mostly in the countries experiencing improvement in food and health conditions. As a consequence, an increase in life expectation has been noticed by some authors ${ }^{(25,32)}$.

They defined ${ }^{(17)}$ osteoporosis as an skeletal condition characterized by reduction of bone mineral density (mass/volume) of a initially well mineralized bone, enough to produce fractures at minimal traumas.

Densitometer is the equipment of choice for bone mineral densitometry, for having a standard error of 5 to $10 \%$ for sensitivity and $2 \%$ for specificity ${ }^{(13)}$.

World Health Organization classified bone density got from densitometry in three categories: normal, as a patient up to one standard deviation from median of young population, up to forty years old, used as reference. The other category is osteopenia, comprising individuals with a densitometric result 1 to 2.5 SD below the reference population, and the last category, as osteoporosis, those with more than $2.5 \mathrm{SD}$ below the reference parameters. 
Entretanto, quando necessitamos estabilizar uma coluna com densidade mineral óssea diminuída, estamos frente a um grande problema e a estabilização deve, obrigatoriamente, incluir a fixação de múltiplos pontos na coluna vertebral, utilizando-se para isto os parafusos transpediculares ${ }^{(19)}$. No entanto, esta é uma prática cirúrgica muito agressiva para o paciente que, de um modo geral, freqüentemente possui outras afecções associadas. Além disso, quando os parafusos transpediculares são inseridos num osso com menor massa óssea, não acontece a mesma fixação que ocorre quando são postos em um osso com densidade mineral normal(3).

Descreveram ${ }^{(15)}$ uma nova técnica para estabilizar a coluna vertebral e que seja capaz também de melhorar a dor em pacientes portadores de hemangioma e tumores líticos metastáticos que acometiam essa região. Esta técnica é chamada de vertebroplastia e consiste na injeção de polimetilmetacrilato dentro do corpo vertebral acometido pela doença, sob visão da fluoroscopia.

Outros autores passaram a indicar a vertebroplastia para o tratamento de pacientes com fratura da coluna vertebral associada à osteoporose e que tinham dor que não melhorava pelos métodos convencionais ou tinham compressão neurológica associada ${ }^{(6,11,21)}$.

A maioria dos trabalhos que encontramos na literatura sobre a vertebroplastia foram revisões de casos clínicos ${ }^{(2,24,33)}$. Por isso, resolvemos realizar um estudo biomecânico para testar a segurança e a capacidade de resistência da vértebra a força de compressão, antes e depois de injetarmos polimetilmetacrilato dentro do corpo vertebral, utilizando a via transpedicular.

Escolhemos modelos obtidos de cadáveres humanos, apesar de sabermos da desvantagem de não formarmos um grupo com características homogêneas de raça, sexo, idade, geometria da vértebra e massa óssea.

Concordamos com ${ }^{(28)}$, que é graças a essa variabilidade, normalmente, encontrada entre os indivíduos da mesma espécie, na natureza, que reside a importância dos trabalhos experimentais que utilizam os modelos obtidos de cadáveres humanos, para demonstrar o comportamento destas estruturas, quando submetidas a um ensaio biomecânico. Por exemplo, a resposta de vértebras lombares de cadáveres humanos a uma força compressiva, após a injeção de cimento acrílico dentro do corpo vertebral.

Discordamos dos autores ${ }^{(27)}$, que propuseram a utilização de modelo de estudo experimental obtido por computador, denominado modelo de elementos finitos, como forma de diminuir a variabilidade encontrada entre os indivíduos da mesma espécie. Salientamos que não encontramos, na natureza, nenhum indivíduo da mesma espécie, totalmente igual ao outro. Por isso, acreditamos que um trabalho experimental tenha que refletir as respostas de um grupo da mesma espécie ao mesmo problema. Entretanto, achamos importante também limitar ao máximo esta variabilidade. E para isso, não escolhemos cadáveres humanos com tumor vertebral ou com fratura antiga na coluna; realizamos a densitometria óssea e afastamos as colunas com resultado inferior a 2,50 desvios padrões, além de usarmos como grupo controle a própria vértebra.

A realização da densitometria foi precedida de um problema referente ao fato de o aparelho para quantificar a massa óssea levar em consideração os tecidos moles, existentes, normalmente, ao redor
Spine fracture associated to osteoporosis is found in 16\% of the white American women after menopause ${ }^{(25)}$. These patients should be treated, in their vast majority, in a conservative manner, with painkillers, NSAIDs, orthesis, rest and physiotherapy.

Surgical treatment of a spine fracture related to osteoporosis is very rare, being indicated only in those patients with untreatable pain with the conservative methods, and associated nerve compression ${ }^{(19,31)}$.

However, when it is necessary to stabilize a spine with reduced mineral density, we face a great problem and stabilization should include multiple points of fixation in the spine, using for this transpedicular screws ${ }^{(19)}$. However, this is a too aggressive surgical practice for patients who generally have frequent association of other pathologies. Furthermore, when these transpedicular screws are inserted in less mineralized bones, the fixation is not as good as when they are placed in a normally mineralized bone ${ }^{(3)}$.

A new technique was described ${ }^{(15)}$ for spine stabilization, able also to improve pain in patients with hemangioma and lythic metastatic tumors involving the region. This technique is called vertebroplasty, and consists in injection of polymethylmetacrylate inside the vertebral body under a fluoroscopic view.

Other authors started to indicate vertebroplasty for treatment of patients with vertebral fracture associated to osteoporosis with pain not improving with conventional treatments, or with neurologic compression associated to these fractures $^{(6,11,21)}$

Most of the publications we found in literature regarding vertebroplasty were reviews of clinical cases ${ }^{(2,24,33)}$. For this reason we decided to perform a biomechanic study to test the safety and resistance of vertebras to compression forces, before and after injection of the acrylic cement inside the vertebral body, through a transpedicular way.

We choose to use models obtained from human cadavers, even though knowing the impossibility to have a group with homogeneous characteristics of race, gender, age, vertebra geometry and bone mass.

We agree with ${ }^{(28)}$ that it is thanks to this variability, normally found between individuals of the same species in nature that is the importance of works using models got from human cadavers, thus demonstrating the behavior of these structures when submitted to a biomechanic assay. For example, the response of human cadaver's lumbar vertebrae to a compressive force after injection of acrylic cement inside the vertebral body.

We disagree from ${ }^{(27)}$ who proposed the use of an experimental study model in computer, called finite elements model, as a way to reduce the variability found between individuals in a same species. We highlight that it is not found in nature any individual, from any species two identical individuals. For this, we believe that an experimental work must reflect the findings of a group of the same species to the same problem. However we also believe that it is important limit as possible this variability. For this we did not choose human 
do osso. Isso foi resolvido, mergulhando o segmento lombar, dentro de um recipiente plástico com água, pois, segundo o fabricante do aparelho Lunar® modelo DPX, o envoltório de tecidos ao redor do osso possui a densidade semelhante à da água.

Os testes que realizamos nas duas colunas que não foram incluídas no estudo serviram para determinar a deformação da vértebra, quando aplicamos uma força de compressão. Encontramos um comportamento semelhante ao descrito por (26) , caracterizado por um gráfico com um pico de força, seguido por uma queda na força e por um segundo pico no aumento da força até atingir um início de patamar.

O primeiro pico significa o limite de resistência da cortical do corpo vertebral. A queda que chamamos de vale corresponde à resistência do osso esponjoso do corpo vertebral associado a participação decrescente da resistência da cortical. O segundo pico ocorre devido à compactação completa das duas corticais do corpo vertebral e da esponjosa, produzindo imagem gráfica de um patamar caracterizado por deformação menor do corpo vertebral, quando submetido a cargas compressivas crescentes.

Faz-se necessário explicar que o corpo vertebral possui um comportamento físico de deformação semelhante a associação de molas, onde a cortical superior e inferior possuem comportamento diferente da camada esponjosa. A vertebroplastia introduz um terceiro elemento dentro corpo vertebral que é o polimetilmetacrilato que pode ou não influenciar na capacidade de resistir à força de compressão crescente.

O nosso trabalho divide em dois grupos as vértebras lombares, e o que difere os dois grupos é o instante do gráfico força versus deformação, descrito acima, que escolhemos para injetarmos o cimento ósseo dentro do corpo vertebral. No grupo A, o ponto escolhido foi após o segundo pico da curva força por deformação e, no grupo $\mathrm{B}$, escolhemos a região logo após o primeiro pico de força.

Demonstramos em nossos resultados que existe uma diferença estatística significante entre o grau de compressão da vértebra íntegra entre os grupos A e B, (Tabela 8). Isto significa que o instante do gráfico força por deformação, escolhido para os dois grupos é verdadeiramente diferente. A introdução do polimetilmetacrilato dentro do corpo vertebral em diferentes graus de compressão da vértebra pode trazer respostas diferentes, quando submetidos a uma força de compressão.

A preparação do corpo para o ensaio é um passo importante como ressalta ${ }^{(13)}$, pois necessitamos diminuir as irregularidades do corpo vertebral para que a aplicação da carga seja feita de maneira uniforme sobre o mesmo. Utilizamos o polimetilmetacrilato para uso odontológico como recheio entre o corpo vertebral e os recipientes cilíndricos metálicos que receberiam a carga compressiva. Para garantir uma distribuição uniforme desse polimetilmetacrilato, desenvolvemos um dispositivo para manter a cimentação de forma homogênea, durante o processo de secagem do cimento.

Outra fase importante do nosso trabalho e que vale a pena ser discutida é a preparação do polimetilmetacrilato a ser injetado dentro do corpo vertebral. Diversos autores ${ }^{(7,8,18,20)}$, descreveram o cimento ósseo como uma substância que possui entre suas qualidades a facilidade do manuseio, ductilidade, elasticidade e resistência. Estas características tornaram o cimento ósseo cadavers with vertebral tumor or previous spine fracture; a bone densitometry was performed and spines with results under 2.5 SD were discharged, and additionally we used the vertebra itself as its own control.

To perform the densitometry, we faced the problem of devices used to measure bone densitometry are drawn taking into account existing soft tissues. This was solved with immersion of the lumbar segment in a plastic recipient with water, since, according to the supplier of Lunar ${ }^{\circ}$ DPX densitometer, soft tissues surrounding the bones have a similar density to water.

The tests we performed in the two spine segments not included in the study were useful for determining vertebra deformation when a compression force was applied. A similar behavior as described by ${ }^{(26)}$ was found, characterized by a graph with a peak of force, followed by a drop in force and a second peak in force increase up to reach a plateau.

The first peak means the resistance limit of the vertebral body cortical. The drop, that we called trough, is correspondent to the resistance of the cancellous bone of the vertebral body. The second peak happens due to the complete compactation of both corticals of the vertebral body and cancellous bone, producing a graphic image of a plateau, a smaller deformation of the vertebral body when submitted to growing compressive loads.

It is necessary to explain that the vertebral body has a physical behavior of deformation similar to coil connections, where the superior and inferior corticals have a different behavior from the cancellous layer. Vertebroplasty introduces a third element inside the vertebral body, the polymethylmetacrylate, which can or not influence the ability of resisting a growing compression force.

Our word is divided into two groups of lumbar vertebrae, and what differentiates both groups is the moment of the graph force versus deformation, above described, we chose to inject bone cement inside the vertebral body. In group A, the chosen moment was after the second peak of force versus deformation curve and in group $B$, just after the first peak of force.

In our results we demonstrate that there is a statistical difference between the degree of compression of the intact vertebra between groups $A$ and $B$ (Table 8). This means that the moment of the graph force versus deformation chosen for both groups in truly different. Introduction of polymethylmetacrylate inside the vertebral body in different degrees of vertebral compression can lead to different responses, when submitted to a compression force.

Preparation of the bodies for the assay was a very important step, as stressed by ${ }^{(13)}$, since we need to reduce the irregularities of the vertebral body so load application is uniform over them. We used odontologic use polymethylmetacrylate as a cushion between the vertebral body and the metallic cylindrical recipients receiving compressive load. For granting uniform distribution of the cement, we developed a device to keep a homogeneous cementation during the drying process of the cement. 
muito utilizado nos procedimentos ortopédicos, principalmente, nas artroplastias.

Acreditamos que a utilização do cimento acrílico não seja também isenta de riscos para o organismo que o está recebendo e para a equipe que esta manuseando o polimetilmetacrilato afir$m a^{(4)}$ que a liberação de calor, durante o processo de polimerização do cimento ósseo, é capaz de causar danos aos tecidos em contato direto com ele, produzindo até necrose deste tecido. Além disso, destaca a liberação de vapores químicos e radicais livres que podem produzir danos hepáticos ao paciente e a equipe.

O uso do polimetilmetacrilato na coluna começou como substância capaz de substituir o corpo vertebral acometido por tumores vertebrais e para dar estabilidade imediata nas artrodeses posteriores em pacientes que possuíam instabilidade e nenhuma condição de remover enxertos ósseos. Salientam ${ }^{(23)}$ que o uso do cimento ósseo desta forma não produz uma estabilidade duradoura e os riscos de problemas futuros são grandes e de difícil solução. Afirmam ${ }^{(38)}$, também após ensaios experimentais, que o cimento ósseo não deveria ser utilizado como enxerto ósseo, em locais de alta solicitação mecânica.

A forma de utilização do cimento ósseo, proposta por(15) possui uma diferença muito grande em relação àquelas que substituem o corpo vertebral por cilindros de polimetilmetacrilato, pois o corpo vertebral não é removido e o cimento acrílico é usado para reforçar as estruturas ósseas do corpo vertebral, aumentando, teoricamente, a resistência do mesmo.

O polimetilmetacrilato que utilizamos em nosso estudo foi o mesmo proposto pelo da marca Howmedica ${ }^{\circledR}$, e é o mesmo utilizado nos procedimentos de artroplastia. Durante o processo de preparação, deixamos o cimento ósseo numa consistência pastosa, semelhante ao glacê de bolo, conforme o preconizado por diversos autores ${ }^{(10,21,24,33)}$

O volume de polimetilmetacrilato injetado em nosso trabalho foi de $9 \mathrm{ml}$. Quanto a esse aspecto, não existe consenso na literatura, pois os autores citados no parágrafo anterior utilizaram volumes que variavam de 2 a $9 \mathrm{ml}$. Definiram ${ }^{(11)}$ a técnica como a injeção percutânea de cimento ósseo no corpo vertebral acometido por uma afecção que diminui sua resistência e preconizaram o volume de polimetilmetacrilato a ser injetado de 2 a $9 \mathrm{ml}$.

Escolhemos a via transpedicular para injetarmos o cimento ósseo, pois, diferentemente da região cervical, em que o corpo vertebral fica mais próximo à pele, na região lombar, o acesso percutâneo pela via anterior pode produzir danos às estruturas anatômicas que rodeiam a coluna lombar. Perfuramos apenas um dos pedículos vertebrais e o canulamos com uma sonda naso gástrica até atingir o interior do corpo vertebral, garantindo, desta maneira, que o cimento ósseo atingisse esse local. Esta escolha está respaldada em trabalhos dos autores ${ }^{(10,12)}$.

O local de extravasamento do cimento ósseo é um parâmetro importante, para avaliarmos a segurança do procedimento vertebroplastia, pois, conforme o local de extravasamento do cimento acrílico através do corpo vertebral, podem ocorrer sérios danos às estruturas nervosas próximas. Essa lesão pode acontecer durante a polimerização do polimetilmetacrilato, que libera calor, ou após seu término, quando produz uma compressão das raízes nervosas ou da medula espinal(35).

Em nossos resultados, anotados nas (Tabela 1), não houve diferença estatística para a freqüência de distribuição do local de saída
Another important phase in our work that deserves to be discussed it preparation of the polymethylmetacrylate to be injected inside the vertebral body. Several authors ${ }^{(7,8,18,20)}$ described bone cement as a substance possessing among its qualities to be easy to handle, ductility, elasticity and resistance. These features made bone cement very much used in orthopedic procedures, mainly arthroplasties.

We believe that the use of acrylic cement is not free of risks, both for the patient and the team. Heat release ${ }^{(4)}$ during the polymerization process can cause damage to tissues in direct contact with it, and can lead even to necrosis. Besides this, gases released during preparation can cause hepatic injuries both to the patient and the surgical team.

The use of polymethylmetacrylate in spine started as a substance able to replace a vertebral body affected by a vertebral tumor, and to give immediate stability to posterior arthrodesis in patients with instability and no conditions for obtaining bone graft. The use of bone cement in this fashion ${ }^{(23)}$ does not give a durable stability and risk of future problems is high and difficult to solve. It is stated(38), also after experimental assays that bone cement should not be used as bone graft in places with high mechanical requirements.

The way to use bone cement, proposed by ${ }^{(15)}$ has a huge difference to those who replace the vertebral body for polymethylmetacrylate cylinders, since the vertebral body is not removed and the acrylic cement is used to reinforce bony structures of the vertebral body, theoretically increasing its resistance.

Polymethylmetacrylate we used in our study was the proposed by the brand Howmedica ${ }^{\circledR}$, and is the same used in arthroplastic surgeries. During preparation process, we preferred to have the cement in a paste consistency, according to recommendation by several authors ${ }^{(10,21,24,33)}$

The volume of injected polymethylmetacrylate in our work was of $9 \mathrm{ml}$. Regarding this aspect, there is no consensus in literature, since the authors above mentioned used volumes ranging from 2 to $9 \mathrm{ml}$. They defined(11) the technique as percutaneous injection of bone cement in a vertebral body which was involved in a process that reduced its resistance and recommended a volume of bone cement ranging from 2 to $9 \mathrm{ml}$.

The transpedicular way was chosen for bone cement injection due to, unlike cervical region, where the vertebral body is closer to the skin, in lumbar region the anterior approach of a percutaneous access can lead to injuries of structures surrounding the spine. We perforated only one of the vertebral pedicles, and cannulated it with a plastic tube to inside the vertebral body, thus allowing the bone cement to reach it. This choice is supported by authors like ${ }^{(10,12)}$.

Place of leakage of bone cement is an important parameter for safety evaluation of vertebroplasty, since according to the local of the leakage, serious damage can be caused to neighbor structures. This injury can happen during polymerization of the cement, which releases heat, or after its ending, when a root or medulla compression can take place ${ }^{(35)}$.

In out results presented in (Tables 1 and 2), there was no statistically significant difference for distribution frequency of 
do cimento ósseo. Entretanto, vale salientar que apenas 6,67\% das trinta vértebras injetadas com cimento ósseo não tiveram nenhum tipo de extravasamento e $26,66 \%$ das vértebras injetadas tiveram saída do polimetilmetacrilato para dentro do canal vertebral.

A análise destes dados nos permite inferir que a consistência do cimento ósseo a ser injetado deve ser um fator importante para o extravasamento, pois um volume de cimento acrílico numa consistência mais sólida diminui os riscos de sua saída através do corpo vertebral, apesar de dificultar a injeção do mesmo pela via transpedicular, quando comparado a um volume mais líquido de cimento ósseo. A consistência de glacê de bolo do cimento ósseo ainda permite o extravasamento através das fissuras ósseas que ocorrem após o ensaio de compressão do corpo vertebral íntegro. Concordamos com ${ }^{(10)}$ quando afirma que é por essas lesões na cortical do corpo vertebral que ocorre a saída do polimetilmetacrilato, durante o procedimento da vertebroplastia.

Estes achados nos ajudam a entender as complicações clínicas, tais como neurites e compressões radiculares ou medulares, encontradas nos trabalhos de revisões, após o procedimento de vertebroplastia $^{(2,10,11,34,35)}$. Portanto, acreditamos que as doenças que promovem destruição da cortical posterior do corpo vertebral detectáveis pela radiografia ou pela tomografia computadorizada constituem contra-indicação absoluta para a vertebroplastia.

A utilização do balão introduzido por via transpedicular até o corpo vertebral e, no seu interior, injeta-se o cimento ósseo, garantindo que o cimento não extravase para fora do corpo vertebral, está sendo preconizada nos últimos dois anos ${ }^{(36)}$. Entretanto, o balão ainda não está disponível para venda na América Latina.

Finalmente, a utilização da fluoroscopia contínua, durante o ato de injeção do cimento ósseo dentro do corpo vertebral, associado ao uso do polimetilmetacrilato misturado com substâncias radiopacas, como o tantálio ou tungstênio, também é uma forma de prevenir extravasamentos e suas complicações ${ }^{(10)}$.

A polimerização do polimetilmetacrilato é uma reação exotérmica, que resulta num aumento da temperatura que varia 40 até 90 graus Celsius nos tecidos próximo ao cimento ${ }^{(4,20)}$.

Em nosso estudo, medimos a temperatura do corpo vertebral, antes e após a injeção do cimento ósseo dentro do corpo vertebral. Para isto, colocamos dois sensores de temperatura junto à parede posterior do corpo vertebral, dentro do canal vertebral, um junto ao pedículo direito e outro ao esquerdo. Após a vertebroplastia, removemos o excesso de cimento, quando presente, de dentro do canal e medimos a temperatura junto ao pedículo direito, por onde foi injetado o cimento ósseo. No outro sensor, localizado do lado oposto, mensuramos a temperatura do pedículo por onde não houve injeção de cimento acrílico. Sabemos que a reação de polimerização demora um período de até 15 minutos. Por isso, em nosso estudo, monitoramos a temperatura durante todo esse período ${ }^{(18)}$.

Os resultados mostram que, em todas as vértebras testadas, houve uma diferença de temperatura estatisticamente significante entre o sensor localizado junto ao pedículo em que foi injetado o cimento acrílico e o outro sensor colocado junto ao pedículo oposto. No primeiro, a temperatura foi mais elevada que o do pedículo oposto. A diferença de temperatura entre os dois sensores, que variou em média de 1,35 a 2,66 ${ }^{\circ} \mathrm{C}$ (Tabelas 2 e 3).

Destacamos que a observação deste dado pode nos levar a pensar que o polimetilmetacrilato injetado na consistência de glacê de bolo não place of leakage of the bone cement. However it is worthy to highlight that only $6.67 \%$ of bone cement injected vertebrae didn't have any leakage and $26.66 \%$ of injected vertebrae had cement leakage into vertebral canal.

Analysis of these data leads us to conclude that the consistency of injected bone cement is an important factor regarding leakage, since a given volume of cement at a more solid consistency reduces the risks of its leakage through the vertebral body, even making difficult its injection through transpedicular way, when compared to a more liquid consistency. The used consistency of bone cement still allowed leakage through clefts presents after the compression assay of intact vertebral body. We agree with $^{(10)}$ who says that it is due to these lesions of vertebral body that polymethylmetacrylate leaks during vertebroplasty.

These findings are helpful to understand clinical complications, such as neuritis and radicular or medullar compressions found in review papers of vertebroplasty $(2,10,11,34,35)$. So, we believe that diseases producing destruction of the posterior cortical of vertebral body which are detectable via radiograph or CT constitute an absolute contra-indication of vertebroplasty.

The use of a balloon via transpedicular to vertebral body, and injection of bone cement inside it (warranting cement not to leak) has been recommended in the last two years ${ }^{(36)}$. However this balloon is not available in Latin America yet.

Finally, the use of continuous fluoroscopy during the injection of bone cement inside the vertebral body, together with use of polymethylmetacrylate mixed to radio-opaque substances is as well a way to prevent leakage and their complications ${ }^{(10)}$.

Polymerization of polymethylmetacrylate is an exothermic reaction resulting in temperature increase ranging from 40 to $90^{\circ} \mathrm{C}$ in tissues surrounding the cement ${ }^{(4,20)}$.

In our study we measured vertebral body temperature, before and after cement injection by the use of two temperature sensors at posterior wall of vertebral body, inside vertebral canal, close to right and left pedicle. After vertebroplasty excess of cement was removed when necessary, from inside the canal and measured the temperature at the right pedicle (where the cement was injected). In the other sensor, placed at the other side, we measured the pedicle temperature (where cement was not injected). It is known that polymerization reaction takes 15 minutes. For this, in our study we monitored the temperature during this period ${ }^{(18)}$.

Results in (Table 3) demonstrate that in all tested vertebrae there was a statistically significant difference in the sensor located close to the pedicle where the cement was injected and the other one, on the opposite side. In the first, temperature was higher than in the opposite side. (Table 4) also demonstrates that there was a temperature difference between the sensors, which ranged from 1.35 to $2.66^{\circ} \mathrm{C}$.

We stress that observation of this data can lead us to think that polymethylmetacrylate injected at cake icing consistency doesn't have the ability to distribute itself inside all the vertebral body, thus there is a higher concentration of bone cement close to the pedicle were it was injected, thus contributing to temperature increase in this area. Therefore 
tem a capacidade de se distribuir por todo o corpo vertebral e, por isso, existe maior concentração do cimento ósseo próximo ao pedículo por onde ele foi injetado, contribuindo, assim, para o aumento da temperatura nesta região. Portanto, discordamos dos autores que, baseados em revisão de ensaios clínicos, acreditavam que o cimento acrílico se distribuísse pelo interior do corpo vertebral(11,15). Recomendamos que para a distribuição ser mais homogênea, a vertebroplastia deve ser feita injetando cimento acrílico, através dos dois pedículos vertebrais.

Analisamos também o tempo que o corpo vertebral demora, em média, para atingir a sua temperatura máxima, após a injeção do cimento ósseo, (Tabela3). Observamos que a temperatura máxima média detectada foi de $31,92^{\circ} \mathrm{C}$, em um tempo de médio 7,97 minutos. Esta temperatura média obtida reflete o quanto o corpo vertebral aumentou sua temperatura em relação àtemperatura inicial, além disso, devemos nesse período ter mais cuidado com o doente, devido a liberação de substâncias tóxicas durante a polimerização do cimento acrilico. Este aumento de temperatura do corpo vertebral não é capaz de causar danos às estruturas anatômicas próximas do corpo vertebral. Entretanto, ela não refletea temperatura real do tecido ósseo mais próximo do polimetilmetacrilato e nem do cimento acrílico que extravasou, mas sabemos que esta temperatura pode atingir até 90 graus Celsius ${ }^{(4)}$.

Acreditamos que a temperatura elevada durante a polimerização do cimento ósseo seja um dos fatores responsáveis pelo alívio da dor e não somente pela estabilidade mecânica conseguida pela presença do cimento acrílico injetado dentro do corpo vertebral, conforme foi relatado em diversos ensaios clínicos ${ }^{(9,14,15,22)}$. De acordo com o trabalho de ${ }^{(4)}$, a temperatura elevada produz necrose dos tecidos que estão imediatamente ao redor do polimetilmetacrilato inclusive das terminações nervosas responsáveis pelo estímulo da dor, o que corrobora nossa posição.

Quando correlacionamos o grau de deformação das vértebras íntegras dos grupos A e B em relação ao ensaio inicial, isto é, sem a vertebroplastia, verificamos, em nossos resultados (Tabelas 6, 7 e 8), que houve uma diferença estatística significante entre os dois grupos. As vértebras do grupo A sofreram uma deformação média de 23,34\% em relação à vértebra íntegra, enquanto que, as do grupo B sofreram uma deformação média de 9,37\%. Desta maneira, asseguramos que a vertebroplastia fosse realizada em diferentes graus de compressão.

Os autores ${ }^{(1,28,29)}$ destacaram, em seus trabalhos, a importância da massa óssea na resistência do corpo vertebral para este suportar as cargas fisiológicas. Entretanto, existem doenças, como os tumores líticos, hemangiomas e osteoporose acentuada, que diminuem a resistência natural do corpo vertebral. A utilização do cimento ósseo para aumentar a resistência do osso, como foi sugerido ${ }^{(5,11)}$, não nos parece ser uma afirmação absolutamente verdadeira, devido aos resultados obtidos em nosso trabalho. Observamos que as vértebras do grupo A que receberam a injeção do polimetilmetacrilato, após a compressão total, apresentaram menor resistência do que a vértebra íntegra. Entendemos que, do ponto de vista da vertebroplastia a resistência apresentada por esse corpo vertebral a carga compressiva, depende do grau de achatamento que a vértebra se encontra.

Os resultados da medida da rigidez, que obtivemos nos ensaios biomecânicos do grupo A, (Tabelas 4 e 5), mostram que existe uma diferença estatística entre a rigidez da vértebra íntegra e após a vertebroplastia. Isto significa que a introdução do cimento ósseo não contribuiu para restaurar a resistência do corpo vertebral, quando submetido a carga de compressão, pois a resistência do corpo verte- we disagree from the authors who in revision of clinical studies believed that the acrylic cement could be distributed inside the vertebral body ${ }^{(11,15)}$. We recommend that, for an homogeneous distribution, vertebroplasty should be performed with injection through both pedicles.

We analyzed as well the time vertebral body takes in average to reach the highest temperature after cement injection (Table 3). We observed that the average highest temperature observed was $31.92^{\circ} \mathrm{C}$, in an average time of 7.97 minutes. This mean temperature observed reflects how much the vertebral body increased its temperature in relation to the initial temperature. Besides this, we should during this time be particularly careful regarding the release of toxic substances during cement polymerization. This temperature increase of the vertebral body in not able to harm anatomical structures close to vertebral body. However, it does not reflect the real temperature of bone tissue closest to polymethylmetacrylate, nor of the leaked cement, however we do know that this temperature can reach $90^{\circ} \mathrm{C}^{(4)}$

We believe that a high temperature during bone cement polymerization is one of the factors responsible not only for pain relief not only due to mechanic stabilization of vertebral body, as reported in several clinical studies ${ }^{(9,14,15,22)}$. According to the work of ${ }^{(4)}$, the high temperature produces necrosis of tissues closest to the cement, including nervous terminations responsible for pain, thus, supporting our position.

When the degree of deformation of intact vertebrae from groups $A$ and $B$ in relation to the initial assay, that is, without vertebroplasty, we find in our results (Table 10) that there was a statistically significant difference between the groups. Group A vertebrae had an average deformation of $23.34 \%$ in relation to intact vertebra, while in Group $B$ the deformation was of $9.37 \%$. This way we made sure that vertebroplasty was performed in different degrees of compression.

The authors ${ }^{(1,28,29)}$ stressed in their works the importance of bone mass in vertebral body resistance to bear its physiological loads. However, there are diseases like lythic tumors, hemangiomas and marked osteoporosis that reduce the natural resistance of the vertebral body. The use of bone cement to increase bone resistance as suggested(5,11), doesn't seem to be a completely true statement, due to the results found in our work. We observed that vertebrae in Group A that received polymethylmetacrylate injection, after total compression presented as less resistant than intact vertebra. We understand that, from a vertebroplasty point of view, resistance of this vertebral body to compressive load is dependent of the degree of flattening the vertebra is.

The results of rigidity measurement that we found in biomechanical assays in Group A (Table 4) demonstrate that there is an statistical difference between intact vertebra rigidity and after vertebroplasty. This means that introduction of bone cement does not contributes to restore the resistance of the vertebral body when submitted to compression load, since vertebral body resistance after vertebroplasty was approximately 66.10\% lesser than intact vertebra.

In group B we observed a different biomechanical behavior. There was no significant statistic difference between average rigidity of intact vertebra and after vertebroplasty. We 
bral, após a vertebroplastia, foi aproximadamente 66,10\% menor do que a vértebra íntegra.

No grupo B, observamos comportamento biomecânico diferente. Não havendo diferença estatística entre as médias de rigidez da vértebra íntegra e após a vertebroplastia. Comprovamos que o polimetilmetacrilato ajudou manter a resistência do corpo vertebral a uma carga compressiva próximo ao da vértebra íntegra.

A comparação da variação da rigidez entre os grupos A e B demonstra que houve uma diferença estatística significante entre eles. Portanto, o grupo B apresentou uma variação menor da rigidez, possuindo um comportamento mais uniforme do que o grupo $A$.

Outro dado importante que obtivemos em nosso estudo biomecânico diz respeito à variação percentual da altura inicial da vértebra até o primeiro pico do ensaio de compressão dos grupos A e B, (Tabela 8). Notamos que a percentagem de perda da altura inicial do grupo A (10,57\%), foi estatisticamente significante em relação ao B (5,29\%), significando que as vértebras do grupo sofreram deformação maior quando submetidas à mesma carga compressiva.

Todos estes achados demonstram que a vertebroplastia, quando indicada antes de as vértebras estarem completamente achatadas, grupo B, pode contribuir para manter a resistência do corpo vertebral, sem, no entanto, ser capaz de se equivaler a resistência da vértebra íntegra.

A vertebroplastiaé uma técnica válida para o tratamento das doenças que diminuem a resistência do corpo vertebral, quando indicadas em vértebras não muito achatadas, e respeitando-se os critérios clínicos de indicação do método. Entretanto, precisamos melhorar a segurança do método para diminuirmos os riscos de danos às estruturas nervosas. Para isso, citamos o uso do balão para impedir extravasamento ${ }^{(16,36)}$. E o emprego de cimentos acrílicos que liberam menor quantidade de calor e com capacidade de integrar-se ao osso sem perder a resistência imediata do polimetilmetacrilato convencional(5,6), são medidas mais recentemente introduzidas que, em curto espaço de tempo, irão trazer benefícios à utilização da vertebroplastia de maneira mais segura.

\section{CONCLUSÕES}

1) A vertebroplastia é uma técnica que pode provocar riscos às estruturas anatômicas próximas ao corpo vertebral, devido à possibilidade de extravasamento do polimetilmetacrilato.

2) Não havendo extravasamento a temperatura observada na cortical posterior do corpo vertebral, após a vertebroplastia, não atinge valores considerados lesivos às estruturas anatômicas dentro do canal vertebral.

3) A resistência biomecânica após a vertebroplastia, depende da quantidade de achatamento observado no corpo vertebral. As vértebras que tiveram achatamento inicial menor, quando foram submetidas a vertebroplastia apresentaram resistência biomecânica maior do que aquelas com deformação inicial maior. found that polymethylmetacrylate helped keeping vertebral body resistance to a compressive load which was close to intact vertebra.

Comparison of variation of the rigidity between groups $A$ and $B$ demonstrates that there was an statistically significant difference between them. Thus, group B presented less variation of the rigidity, whit a more uniform behavior than observed in group $A$.

Another important data we found is in regard to percentual variation of initial height of the vertebra to the first peak of compression assay of groups $A$ and $B$ (Table 12). We noticed that the percentage of initial height lost at group $A(10.57 \%)$ was statistically significant in relation to group B (5.29\%). This means that vertebrae of this group suffered more deformation when underwent the same compressive load.

All these findings demonstrate that vertebroplasty, when indicated before vertebrae are completely flattened, group $B$ can contribute to keeping the resistance of the vertebral body, without however being able to keep the same resistance of an intact vertebra.

Vertebroplasty is a valid technique for treatment of diseases reducing vertebral body resistance, when indicated in vertebrae not very much flattened, respecting the clinical criteria for method indication. However, we need to improve the safety of the method to reduce risks of injury to nervous structures. For this we mentioned the use of a balloon to avoid leakage ${ }^{(16,36)}$. And the use of acrylic cements releasing lower amounts of heat and ability to integrate to the bone without loosing the resistance conventional polymethylmetacrylate has ${ }^{(5,6)}$ are measures more recently introduced which, in a short term will bring benefits helping to perform more safe vertebroplasties.

\section{CONCLUSIONS}

1) Vertebroplasty is a technique that can harm anatomical structures that are close to vertebral body, due to the possibility of polymethylmetacrylate leakage.

2) Once there is no leakage, temperature observed at posterior cortical of vertebral body, after vertebroplasty, does not reach values considered as harmful to anatomical structures inside the vertebral canal.

3) Biomechanical resistance after vertebroplasty is dependent on how much the vertebral body was flattened. Vertebrae with less initial flattening, when submitted to vertebroplasty presented a higher biomechanical resistance than those with a more important deformation. 


\section{REFERÊNCIAS BIBLIOGRÁFICAS}

1. Alho, A: Mineral and mechanics of bone fractures. A review of fixation methods. Acta Orthop Scand 64: 227-32, 1993.

2. Barr, J.D., Barr, M.S., Lemley, T.J. \& MacCann, R.M.: Percutaneous vertebroplasty for pain relief and spinal stabilization. Spine 25: 923-28, 2000.

3. Bennett, G.J., Serhan, H.A., Sorini, P.M. \& Willis, B.H.: An experimental study of lumbar destabilization. Restabilization and bone density. Spine 22: 1448-53, 1997.

4. Berman, A.T, Reid, J.S., Yanicko, D.R., Sih, G.C. \& Zimmerman, M.R.: Thermally induced bonenecrosis in the rabbits. Clin. Orthop. 186: 284-92, 1984.

5. Bo, B., Laith, M.J., Kummer, F.J. \& Spivak, J.M.: The use of na injectable, biodegradable calcium phosphate bone substitute for prophylactic augmentation of osteoporotic vertebrae and the management of vertebral compression fractures. Spine 24: 1521-1526, 1999

6. Bostrom, M.P.G. \& Lane, J.M.: Future directions augmentation of osteoporotic vertebral bodies. Spine 22: 38-42, 1997. Supplement 24

7. Cloft, H.J., Easton, D.N., Jensen, M.E., Kallmes: D.F. \& Dion, J.E.: Exposure of medical personnel to methylmethacrylate vapor during percutaneous vertebroplasty. J. Neuroradiol $[\mathrm{Am}] 20$ : 352-53, 1999.

8. Convery, F.R., Gunn, D., Hugues, D. \& Martin, W.E.: The relative safety of polymethylmethcrylate. J. Bone and Joint Surg. $[A]$ 57:57-64, 1975.

9. Cortet, B., Cotten, A., Deprez, X., Deramond, H., Lejeune, J.P., Leclerc, X., Chastanet, P., Duquesnoy, B. \& Delcambre, B.: Intérêt de la vertébroplastie couplée á une décompression chirurgicale dans le traitement des angiomes vertébraux agressifs. A propos de trois cãs. Rev. Rhum.[Fr] 61:16-22, 1994.

10. Cotten, A., Dewatre, F., Cortet, B., Assaker, R., Leblond, D., Duquesnoy, B., Chastanet, P. \& Clarisse, J.: Percutaneuous vertebropasty for osteolytic metastases and myeloma: effcts of the percentage of lesion filling and leakage of methylmetacrilato at clinical folow-up. Radiology 200: 525-30, 1996.

11. Cotten, A. \& Duquesnoy, B.: Vertebroplasty: current data and future potencial. Rev. Rhum [Engl] 64: 645-9, 1997.

12. Dufresne, A.C., Brunet, E., Sola-Martinez, M.T., Rose, M. \& Chiras, J.: Vertébroplastie percutanée de la charniére cervico dorsale par voie antérieure. Technique et résultats. A propos de neufcas. J. Neuroradiol 25: 123-28, 1998.

13. Edmondston, S.J., Singer, K.P., Day, R.E., Price R.I. \& Breidahl, P.D.: Ex vivo estimation of thoracolumbar vertebral body compressive strength: the relative contributions of bone densitometry and vertebral morphometry. Osteoporosis. Int 7:142-48, 1997.

14. Feydy, A., Cognard, C., Miaux, Y., Sola Martinez, M.T., Weill, A., Rose M. \& Chiras, J.: Acrylic vertebroplasty in symptomatic cervical vertebral haemangiomas: report of 2 cases. Neuroradiology 38:389-391, 1996

15. Galibert, P., Deramond, H., Rosat, P. \& Le Gars, D.: Note préliminaire sur le traitement desangiomes vertébraux par vertébroplastie acrylique percutanée. Neurochirurgie 33:166-68, 1987.

16. Garfim, R.S., Lane, J.M., Reiley, M.A. \& Yuan, H.A.: Symposium on Advances in treating osteoporotic vertebral bod compression fractures. Chicago, 1999.

17. Glaser, D.L. \& Kaplan, F.S.: Definition and clinical presentation. Spine 22:12-16, 1997. Supplement 24.

18. Hass, S.S., Braver, G.M. \& Dickson, G.: Characterization of polymethy-methacrylate bone cement. J. Bone Joint Surg. [Am] 57:380-391, 1975
19. Hu, S.S.: Internal fixation in the osteoporotic spine. Spine 22:43 48, 1997. Supplement 24.

20. Jefferriss, C.D., Lee, A.J.C. \& Ling, R.S.M.: Thermal aspects of self-curing polymethylmethacrylate. J. Bone Joint. Surg. $[\mathrm{Br}] 57$ : 511-518, 1975

21. Jensen, M.E., Evans, A. J., Mathis, J.M., Kallmes, D.F., Cloft, H.J. \& Dion, J.E.: Percutaneous polymethylmethacrylate vertebroplasty in the treatment of osteoporotic vertebral compression fractures: techinical aspects. Am. J. Neuroradiol 18:1987-904, 1997.

22. Lapras, C., Motolesse, C., Deruty, R., Lapras, C., Jr., Remond, J. \& Dusquesnel, J.: Injectin percutaneé de méthil métaccrylate dans traitement de l'ostéoprose et ostéolyse vertébralegrave. Ann. Chir. [Fr] 43:371-76, 1989

23. Macfee, P.C., Bohlman, H.H. \& Ducker, T.: Failure of stabilization of the spine with methylmethacrylate. J. Bone Joint Surg. [Am] 68: 1145-1157, 1986.

24. Mathis, J.M., Petri, M. \& Naff, N.: Percutaneous vertebroplasty treatment of steroid-induced osteoporotic compression fractures. Arthritis Rheum 41: 171-5, 1998.

25. Melton, L. J., III.: Epidemiology of spinal osteoporosis. Spine 22: 2-11, 1997. Supplement 24. 33. Menezes, L.A.F.: Compressão axial de corpos vertebrais humanos ensaios com cargas lentas e progressivas. São Paulo, 1987. 72p. Dissertação (Mestrado) Faculdade de Medicina, Universidade de São Paulo.

26. Menezes, L.A.F.: Compressão axial de corpos vertebrais humanos ensaios com cargas lentas e progressivas. Sâo Paulo, 1987. 72 p. Dissertação (Mestrado) - Faculdade de Medicina, Universidade de São Paulo.

27. Mizrahi, J., Silva, M., Keaveny, T. \& Edwards, W.: Finite element stress anaysis of the normal and osteoprotic lumbar vertebral body. Spine 18: 2088-2096, 1993.

28. Mosekilde, L.: Vertebral structure and strength in vivo and in vitro. Calcif Tissue Ind 53: 121-26, 1993. Supplement 1.

29. Myers, E.R. \& Wilson, S.E.: Biomechanics of osteoporosis and vertebral fracture. Spine 22: 25-31, 1997. Supplement 24.

30. Rossi, J.D.M.B.A., Costa, R.C. \& Leivas, T.P.: Avaliação mecânica de compósitos de hidroxi-apatita polimetilmetacrilato. Rev. Bras Ortop 28: 167-171, 1993.

31. Tamayo-Orozco, J., Arzac-Palumbo, P., Héctor, P.V. H., Mota Bolfeta, R. \& Fuentes, F.: VertebraL fractures associated with osteoporosis: patient management. Am J Med. 103: 44-50, 1997.

32. Tosteson, A.N.A.: Quality of life in the economic evaluation of osteoporosis prevention and

33. Wälchli, B., Berlemann, U.\& Heini, P.F.: Vertebroplasty techique and first clinical results on the treatment of osteoporotic. Spine 25: 26-27, 2000. Supplement 26.

34. Weill, A., Chiras, J., Simon, L.M., Rose, M., Sola-Martinez, T.\& Enkaoua, E.: Spinal metastases: indications for and results of percutaneous injection of acrylic surgical cement. Radiology 199: 241-247, 1996.

35. Wilkes, R.A., Mackinnom, J.G. \& Thomas, W.G. Neurological deterioration after cement injection into a vertebral body. J bone Joint Surg. \{Br\} 76: 155, 1994.

36. Wilson, D.R., Myers, E.R., Mathis, J.M., Scribner, R.M., Conta, J.A., Reiley, M.A., Talmadge, K.D. \& Hayes, W.C.: Effect of augmentation on the mechanics of vertebral wedge fractures. Spine 25: 158-165. 2000. 